\title{
BMR
}

\section{Leptin receptor expression and GIn223Arg polymorphism as prognostic markers in oral and oropharyngeal cancer}

P.R.S. Rodrigues ${ }^{1}$, L.L. Maia ${ }^{2}$, M. Santos ${ }^{3}$, G.T. Peterle ${ }^{2}$, L.U. Alves ${ }^{1}$, J.T. Takamori' ${ }^{1}$, R.P. Souza ${ }^{4}$, W.M. Barbosa ${ }^{2}$, A.M.C. Mercante ${ }^{1}$, F.D. Nunes ${ }^{5}$, M.B. Carvalho ${ }^{1}$, E.H. Tajara ${ }^{6}$, I.D. Louro ${ }^{2}$ and A.M.A. Silva-Conforti2,7

${ }^{1}$ Laboratório de Biologia Molecular, Hospital Heliópolis, São Paulo, SP, Brasil

${ }^{2}$ Programa de Pós-Graduação em Biotecnologia, Universidade Federal do Espírito Santo, Vitória, ES, Brasil

${ }^{3}$ Escola Multicampi de Ciências Médicas do Rio Grande do Norte, Universidade Federal do Rio Grande do Norte, Caicó, RN, Brasil ${ }^{4}$ Instituto do Câncer, Arnaldo Vieira de Carvalho, São Paulo, SP, Brasil ${ }^{5}$ Departamento de Patologia Bucal, Faculdade de Odontologia, Universidade de São Paulo, São Paulo, SP, Brasil

${ }^{6}$ Departamento de Biologia Molecular,

Faculdade de Medicina de São José do Rio Preto, São José do Rio Preto, SP, Brasil

${ }^{7}$ Departamento de Biologia, Universidade Federal do Espírito Santo, Alegre, ES, Brasil

Corresponding author: A.M.A. Silva-Conforti

E-mail: adriana.biomol@gmail.com

Genet. Mol. Res. 14 (4): 14979-14988 (2015)

Received June 6, 2015

Accepted September 8, 2015

Published November 24, 2015

DOI http://dx.doi.org/10.4238/2015.November.24.5

ABSTRACT. The leptin gene product is released into the blood stream, passes through the blood-brain barrier, and finds the leptin receptor (LEPR) in the central nervous system. This hormone regulates food 
intake, hematopoiesis, inflammation, immunity, differentiation, and cell proliferation. The LEPR Gln223Arg polymorphism has been reported to alter receptor function and expression, both of which have been related with prognostics in several tumor types. Furthermore, several studies have shown a relationship between the Gln223Arg polymorphism and tumor development, and its role in oral and oropharyngeal squamous cell carcinoma is now well understood. In this study, 315 DNA samples were used for LEPR Gln223Arg genotyping and 87 primary oral and oropharyngeal squamous cell carcinomas were used for immunohistochemical expression analysis, such that a relationship between these and tumor development and prognosis could be established. Homozygous LEPR Arg223 was found to be associated with a 2-fold reduction in oral and oropharyngeal cancer risk. In contrast, the presence of the Arg223 allele in tumors was associated with worse disease-free and disease-specific survival. Low LEPR expression was found to be an independent risk factor, increasing the risk for lymph node metastasis 4-fold. In conclusion, the Gln223Arg polymorphism and LEPR expression might be valuable markers for oral and oropharyngeal cancer, suggesting that LEPR might serve as a potential target for future therapies.

Key words: LEPR expression; Gln223Arg; Prognostic marker; Head and neck cancer

\section{INTRODUCTION}

Head and neck cancer (HNC) is a significant cause of morbidity and mortality worldwide, and an estimated 600,000 new cases and 300,000 deaths each year can be attributed to this disease (Bauman et al., 2012). The 5-year survival rate for $\mathrm{HNC}$ is approximately $50 \%$ and treatment is mainly based on radiotherapy in combination with surgery and/or chemotherapy (Ferlay et al., 2008; Leemans et al., 2011). HNC has a multifactorial etiology involving smoking and drinking habits, human papillomavirus infection, and genetic factors (Gallì et al., 2009).

Leptin is a hormone released into the bloodstream and transferred through the bloodbrain barrier, eventually reaching the leptin receptor LEPR (also known as OBR) located at the plasma membrane of hypothalamic cells. Leptin regulates food intake, hematopoiesis, inflammation, immunity, cell differentiation, and proliferation (Lavens et al., 2006; Snoussi et al., 2006; Andò and Catalano, 2011).

LEPR is a member of a family of cytokine class 1 receptors (Vaisse et al., 1996). Upon ligand binding, LEPR undergoes structural changes, which tethers Janus kinase (JAK) molecules thus enabling cross phosphorylation. This step is needed for the phosphorylation of signal transducer and activator of transcription (STAT) molecules at the cytoplasmic region of the receptor. STAT3 autodimerizes after phosphorylation of JAK2 and translocates into the nucleus, where it activates transcription at specific gene promoters. Among the various genes induced by STAT3 are those encoding enzymes involved in the development of many tumors (Frühbeck, 2006; Lavens et al., 2006; Anuradha et al., 2012; Liu et al., 2013). 
Several LEPR polymorphisms have been described in humans. An A/G transition at nucleotide 668 converts a glutamine to an arginine at codon 223 (Gln223Arg) of the protein. This transition results in an exchange of a neutral amino acid for one with a positive charge, altering receptor function and signaling capacity and modifying circulating leptin levels (Anuradha et al., 2012). This polymorphic variant is located inside the extracellular domain coding region and affects the entire structure of the receptor (Li et al., 2012).

Previous studies have correlated the Gln223Arg polymorphism and LEPR expression with the development and prognosis of several tumors such as breast (Park and Scherer, 2011; Anuradha et al., 2012; He and Chen, 2012; Wazir et al., 2012), lung (Li et al., 2012), stomach (Kim et al., 2012), and prostate (Hoon et al., 2008) tumors. However, conclusive data are not yet available for $\mathrm{HNC}$ and studies on this area are scarce. Therefore, the present study aimed to analyze the Gln223Arg polymorphism and LEPR expression and their association with the development, prognosis, and survival of patients with oral and oropharyngeal cancer.

\section{MATERIAL AND METHODS}

\section{Ethical approval}

This study was approved by the Ethics Committee in Research of the Heliópolis Hospital (CEP \#446) and a written informed consent was obtained from all patients enrolled.

\section{Samples}

Samples were collected by the Head and Neck Genome Project (GENCAPO), a collaborative consortium created in 2002 with more than 50 researchers from institutions in Brazil. In this study, 315 DNA samples were obtained and used for LEPR Gln223Arg polymorphism genotyping, consisting of samples from 186 (59.0\%) individual controls with no history of cancer and $129(41.0 \%)$ patients with oral and oropharyngeal squamous cell carcinomas. LEPR immunohistochemical analysis was performed on tumor tissue samples from 87 patients who had oral and oropharyngeal squamous cell carcinomas and had been surgically treated at the Head and Neck Surgery Department of Heliópolis Hospital and Arnaldo Vieira de Carvalho Cancer Hospital, São Paulo, Brazil, during the period of January 2002 to December 2009. The clinical follow-up was at least 48 months after surgery. Previous surgical or chemotherapeutic treatment, distant metastasis, no removal of cervical lymph nodes, and positive surgical margins were exclusion criteria (UICC, 2009).

Among the individuals analyzed, the mean (SD) age was 54.2 years $( \pm 11.1$ years), with $173(93.0 \%)$ men and $13(7.0 \%)$ women in the control group. For patients with HNC, the mean age was 54.9 years ( \pm 10.7 years), including $104(80.6 \%)$ men and $25(19.4 \%)$ women (Table 1). Regarding the anatomical localization of the tumor, $95(73.6 \%)$ were on the oral cavity and $34(26.4 \%)$ on the oropharynx. The clinical-pathological characteristics of the tumors are described in Table 2.

\section{Genotyping}

Genomic DNA was extracted from peripheral blood samples of 309 individuals 
(patients with cancer and controls) as previously described (Miller et al., 1988). Genotypes were determined by polymerase chain reaction (PCR)-restriction fragment length polymorphism. $L E P R$ exon 6 was amplified using primers described by Snoussi et al. (2006) and analyzed for the Gln223Arg polymorphism (rs1137101). Selected amplification primers were 5'AAA CTC AAC GAC ACT CTC CTT-3' and 5'-TGA ACT GAC ATT AGA GGT GAC3 ', which produced an 80-bp fragment. PCR conditions were as follows: a $25-\mu \mathrm{L}$ reaction mixture containing $200 \mathrm{ng}$ genomic DNA, $10 \mathrm{mM}$ Tris-HCl, $\mathrm{pH} 8.3,50 \mathrm{mM} \mathrm{KCl}, 200 \mu \mathrm{M}$ of each deoxyribonucleoside 5'-triphosphate, $1.5 \mathrm{mM} \mathrm{MgCl}, 1 \mathrm{U}$ Taq DNA polymerase (Life Technologies Inc. ${ }^{\circledR}$, Rockville, MD, USA), and 25 pmol of each primer (Biobrás ${ }^{\circledR}$, São Paulo, SP, Brasil). PCR amplification was initiated with a melting step of 5 min at $94^{\circ} \mathrm{C} ; 35$ cycles of $30 \mathrm{~s}$ at $94^{\circ} \mathrm{C}, 45 \mathrm{~s}$ at $52^{\circ} \mathrm{C}$, and $45 \mathrm{~s}$ at $72^{\circ} \mathrm{C}$; with a 5 -min extension at $72^{\circ} \mathrm{C}$. PCR products were digested overnight with MspI (New England Biolabs ${ }^{\circledR}$, Beverly, MA, USA) following the manufacturer instructions. Restriction fragments were resolved on a $12 \%$ non-denaturing polyacrylamide gel. The single nucleotide polymorphism Arg223 in the LEPR gene was characterized by two distinctive fragments of 58 and $22 \mathrm{bp}$, whereas the LEPR Gln223 wildtype allele was identified by a single 80 -bp fragment.

\section{Tissue microarray}

Tissue microarrays generated using buffered formalin-fixed paraffin-embedded tissue sections from samples from 87 patients with primary oral and oropharyngeal squamous cell carcinomas treated at the Head and Neck Surgery Department of Heliópolis Hospital, São Paulo, SP, were used for immunohistochemistry (IHC) analysis. Histological characterization of all samples was done by hematoxylin and eosin staining, followed by IHC analysis of tissue microarrays (TMA). Each sample was represented by $2 \times 1 \mathrm{~mm}$ cylinders in the TMA slide (Beecher Instruments ${ }^{\circledR}$, Silver Spring, MD, USA).

\section{IHC}

An anti-LEPR polyclonal antibody (Santa Cruz Biotechnology ${ }^{\circledR}$, Dallas, TX, USA) was used in the IHC reaction at 1:50 dilution (Rimm et al., 2001; Hedvat et al., 2002; Hsu et al., 2002). Positive and negative controls (absence of primary antibody) were used for reaction quality control. Sample scoring was performed by semi-quantitative microscopic analysis, considering the number of stained tumor cells and signal intensity. Two spots were evaluated for each sample and a mean score was calculated. Considering the percentage of LEPR immune-positive tumor cells, a score of 1 was given when $\leq 10 \%$ cells were positive, 2 when $10-50 \%$ cells were positive, and 3 when $\geq 50 \%$ cells were positive. Signal intensity was scored as weak (1), moderate (2), or strong (3). Both scores were multiplied (Soini et al., 2000; Campos et al., 2009) and the resulting score was used to categorize LEPR expression as low $(<4)$ or high $(\geq 4)$.

\section{Statistical analysis}

Chi-square and Fisher exact tests were used for association analysis and confirmation was obtained by the Lilliefors test (significance was considered when $\mathrm{P}<0.05$ ). Multivariate- 
logistic regression was used to obtain odds ratios (ORs) and 95\% confidence intervals (CIs). Survival was calculated by the number of months between surgery and death for each patient or the last appointment when the patient was alive. In order to calculate disease-free survival, the time endpoint was the date of disease relapse. The Kaplan-Meier model was used for survival analysis, using the Wilcoxon $\mathrm{P}$ value and the Cox proportional hazards to adjust $\mathrm{P}$ values and obtain hazard ratios (HRs). Statistical calculations were performed using the EpiInfo $^{\circledR}$ v3.4.3, 2007 and Statsoft Statistica ${ }^{\circledR}$ v7.0.61.0 softwares.

\section{RESULTS}

\section{LEPR GIn223Arg polymorphism}

The LEPR Gln223Arg polymorphism frequencies were determined to be as follows: $60(46.5 \%)$ patients with cancer were genotyped as carrying the homozygous wild-type allele $\mathrm{Gln} / \mathrm{Gln}, 61(47.3 \%)$ as $\mathrm{Gln} / \mathrm{Arg}$, and $8(6.2 \%)$ as Arg/Arg. In the control group, 68 (36.5\%) individuals were genotyped as Gln/Gln, 92 (49.5\%) as Gln/Arg, and 26 (14.0\%) as Arg/Arg. The observed genotype frequencies of the LEPR Gln223Arg polymorphism were at HardyWeinberg equilibrium in the controls $(\mathrm{P}=0.563)$. The Arg223 allele in the homozygote state was more frequent in control individuals than in patients, with a significant association $(\mathrm{P}=$ 0.045). Multivariate analysis showed that the Arg/Arg genotype was an independent factor for $\mathrm{HNC}$ development, representing a decreased risk of approximately 2.5 times in relation to the wild-type genotype $(\mathrm{Gln} / \mathrm{Gln})(\mathrm{OR}=0.40,95 \% \mathrm{CI}=0.16-0.97$; Table 1$)$. However, the genotype Gln/Arg showed no relation to risk.

\begin{tabular}{|c|c|c|c|c|c|c|c|}
\hline \multirow[t]{2}{*}{ Features } & \multicolumn{2}{|c|}{ Patients } & \multicolumn{2}{|c|}{ Controls } & \multirow[t]{2}{*}{$\mathrm{P}$} & \multicolumn{2}{|c|}{ Multivariate analysis } \\
\hline & No. & $(\%)$ & No. & $(\%)$ & & OR $(95 \% \mathrm{CI})^{\mathrm{a}}$ & $\mathrm{P}^{\mathrm{b}}$ \\
\hline \multicolumn{8}{|l|}{ Gender } \\
\hline Female & 25 & (19.4) & 13 & (7.0) & \multirow[t]{2}{*}{0.001} & 1 & \\
\hline Male & 104 & (80.6) & 173 & (93.0) & & $0.12(0.04-0.35)$ & $<0.001$ \\
\hline \multicolumn{8}{|c|}{$\begin{array}{l}\text { Age in years } \\
\text { (mean, 54.5, d.f. } \pm 10.9)\end{array}$} \\
\hline$\leq 55$ & 66 & $(51.2)$ & 105 & $(56.5)$ & \multirow[t]{2}{*}{0.497} & - & - \\
\hline$>55$ & 63 & $(48.8)$ & 81 & $(43.5)$ & & - & - \\
\hline \multicolumn{8}{|l|}{ Smoker } \\
\hline No & 59 & $(45.7)$ & 103 & $(55.4)$ & \multirow[t]{2}{*}{0.039} & 1 & \\
\hline Yes & 70 & (54.3) & 83 & (44.6) & & $3.57(1.48-8.61)$ & 0.005 \\
\hline \multicolumn{8}{|c|}{ Drinking habit } \\
\hline No & 34 & (26.4) & 96 & $(51.6)$ & \multirow[t]{2}{*}{$<0.001$} & 1 & \\
\hline Yes & 95 & (73.6) & 90 & (48.4) & & $2.42(0.98-5.96)$ & 0.055 \\
\hline \multicolumn{8}{|c|}{$L E P R$ genotype Gln223Arg } \\
\hline $\mathrm{Gln} / \mathrm{Gln}$ & 60 & $(46.5)$ & 68 & $(36.5)$ & \multirow[t]{4}{*}{0.045} & 1 & \\
\hline $\mathrm{Gln} / \mathrm{Arg}$ & 61 & (47.3) & 92 & $(49.5)$ & & $0.78(0.47-1.28)$ & 0.317 \\
\hline $\mathrm{Arg} / \mathrm{Arg}$ & 8 & $(6.2)$ & 26 & $(14.0)$ & & $0.40(0.16-0.97)$ & 0.042 \\
\hline Total & 129 & $(41.0)$ & 186 & $(59.0)$ & & & \\
\hline
\end{tabular}

The Gln223Arg polymorphism did not show a significant association with tumor size ( $\mathrm{P}=0.406)$, lymph node metastases $(\mathrm{P}=0.430)$, lymphatic invasion $(\mathrm{P}=0.824)$, or perineural 
invasion $(\mathrm{P}=0.621)$, but was significantly associated with differentiation grade $(\mathrm{P}=0.038$; Table 2$)$. It was also significantly associated with disease relapse $(\mathrm{P}=0.003)$ and diseasespecific death $(\mathrm{P}=0.039$; Table 2$)$.

\begin{tabular}{|c|c|c|c|c|c|c|c|c|c|c|}
\hline \multirow[t]{3}{*}{ Features } & \multicolumn{5}{|c|}{ Genotype Gln223Arg } & \multicolumn{5}{|c|}{ Expression level } \\
\hline & \multicolumn{2}{|c|}{ Total } & \multirow[t]{2}{*}{$\mathrm{Gln} / \mathrm{Gln}$} & \multirow{2}{*}{$\begin{array}{c}\mathrm{Gln} / \mathrm{Arg} \\
+\mathrm{Arg} / \mathrm{Arg}\end{array}$} & \multirow[t]{2}{*}{$P$} & \multicolumn{2}{|c|}{ Total } & \multirow[t]{2}{*}{ Low } & \multirow[t]{2}{*}{ High } & \multirow[t]{2}{*}{$\mathrm{P}$} \\
\hline & $\mathrm{N}$ & $(\%)$ & & & & $\mathrm{N}$ & $(\%)$ & & & \\
\hline \multicolumn{11}{|l|}{ Tumor size $(\mathrm{T})^{\mathrm{a}}$} \\
\hline $\mathrm{T} 1+\mathrm{T} 2$ & 50 & $(38.8)$ & 21 & 29 & \multirow[t]{3}{*}{0.406} & 34 & $(39.1)$ & 15 & 19 & \multirow[t]{3}{*}{0.844} \\
\hline T3 & 31 & $(24.0)$ & 13 & 18 & & 21 & $(24.1)$ & 9 & 12 & \\
\hline $\mathrm{T} 4$ & 48 & $(37.2)$ & 26 & 22 & & 32 & $(36.8)$ & 16 & 16 & \\
\hline \multicolumn{11}{|l|}{ Lymph node $(\mathrm{N})^{\mathrm{a}}$} \\
\hline Absent $(\mathrm{N}-)$ & 64 & (49.6) & 32 & 32 & \multirow[t]{2}{*}{0.430} & 33 & $(37.9)$ & 9 & 24 & \multirow[t]{2}{*}{0.006} \\
\hline Present $(\mathrm{N}+)$ & 65 & (50.4) & 28 & 37 & & 54 & $(62.1)$ & 31 & 23 & \\
\hline \multicolumn{11}{|l|}{ Differentiation } \\
\hline Well differentiated & 52 & $(40.3)$ & 21 & 31 & \multirow[t]{3}{*}{0.038} & 38 & $(43.7)$ & 18 & 20 & \multirow[t]{3}{*}{0.761} \\
\hline Moderately differentiated & 69 & $(53.5)$ & 38 & 31 & & 42 & $(48.3)$ & 18 & 24 & \\
\hline Poorly differentiated & 8 & $(6.2)$ & 1 & 7 & & 7 & $(8.0)$ & 4 & 3 & \\
\hline \multicolumn{11}{|l|}{ Lymphatic invasion } \\
\hline Negative & 61 & (47.3) & 29 & 32 & \multirow[t]{2}{*}{0.824} & 28 & $(32.2)$ & 14 & 14 & \multirow[t]{2}{*}{0.604} \\
\hline Positive & 68 & $(52.7)$ & 31 & 37 & & 59 & $(67.8)$ & 26 & 33 & \\
\hline \multicolumn{11}{|l|}{ Perineural invasion } \\
\hline Negative & 93 & $(72.1)$ & 42 & 51 & \multirow[t]{2}{*}{0.621} & 65 & $(74.7)$ & 26 & 39 & \multirow[t]{2}{*}{0.054} \\
\hline Positive & 36 & (27.9) & 18 & 18 & & 22 & $(25.3)$ & 14 & 8 & \\
\hline \multicolumn{11}{|l|}{ Disease relapse } \\
\hline No & 50 & $(38.8)$ & 30 & 20 & \multirow[t]{3}{*}{0.003} & 35 & $(40.2)$ & 13 & 22 & \multirow[t]{3}{*}{0.149} \\
\hline Yes & 52 & $(40.3)$ & 16 & 36 & & 45 & $(51.7)$ & 24 & 21 & \\
\hline Not available* & 27 & (20.9) & 14 & 13 & & 7 & $(8.0)$ & 3 & 4 & \\
\hline Disease specific death & & & & & & & & & & \\
\hline No & 59 & $(45.7)$ & 31 & 28 & 0.039 & 42 & $(48.3)$ & 16 & 26 & 0.123 \\
\hline Yes & 41 & (31.8) & 13 & 28 & & 36 & $(41.4)$ & 20 & 16 & \\
\hline Not available* & 29 & (22.5) & 16 & 13 & & 9 & $(10.3)$ & 4 & 5 & \\
\hline Total & 129 & $(100.0)$ & 60 & 69 & & 87 & $(100.0)$ & 40 & 47 & \\
\hline
\end{tabular}

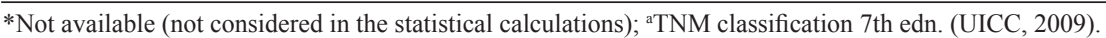

Multivariate analysis showed that presence of the Arg223 allele was an independent marker of disease relapse representing an increased risk of over 3-fold when compared to the absence of this allele $(\mathrm{OR}=3.30,95 \% \mathrm{CI}=1.37-7.93)$, but the same association was not found for disease-specific death $(\mathrm{OR}=2.40,95 \% \mathrm{CI}=0.95-6.08$; Table 3$)$.

Disease-free and disease-specific survival were significantly correlated with the Gln223Arg polymorphism ( $\mathrm{P}=0.001$ and $\mathrm{P}=0.012$, respectively). According to a 24-month after-surgery follow-up, approximately $60 \%$ of patients with at least one Arg 223 allele presented disease relapse, as compared to approximately $30 \%$ of recurrence in patients without the Arg223 allele (Figure 1A). Additionally, according to a 36-month after-surgery follow-up, approximately $60 \%$ of patients with at least one Arg223 allele died of disease-specific causes, as compared to approximately $20 \%$ of deaths in patients without the Arg223 allele (Figure 1B). Multivariate analysis revealed that the presence of the Arg223 allele in the LEPR gene was an independent marker for early disease relapse and disease-specific death, with a 2-fold increased risk when compared to absence of this allele (respectively, $\mathrm{HR}=2.38,95 \% \mathrm{CI}=$ 1.29-4.39 and $\mathrm{HR}=2.11,95 \% \mathrm{CI}=1.05-4.24$; Table 4). 
Table 3. Multivariate analysis of the relationships between clinical and pathological tumor features with the LEPR gene polymorphism and protein expression.

\begin{tabular}{|c|c|c|c|c|c|c|}
\hline \multirow[t]{2}{*}{ Features } & \multicolumn{2}{|c|}{ Lymph node $(\mathrm{N})^{\mathrm{c}}$} & \multicolumn{2}{|l|}{ Disease relapse } & \multicolumn{2}{|c|}{ Disease-specific death } \\
\hline & OR $(95 \% \mathrm{CI})^{\mathrm{a}}$ & $\mathrm{P}^{\mathrm{b}}$ & OR $(95 \% \mathrm{CI})^{\mathrm{a}}$ & $\mathrm{P}^{\mathrm{b}}$ & OR $(95 \% \mathrm{CI})^{\mathrm{a}}$ & $\mathrm{P}^{\mathrm{b}}$ \\
\hline \multicolumn{7}{|l|}{ LEPR expression } \\
\hline High & 1 & - & - & - & - & \\
\hline Low & $3.75(1.40-10.04)$ & 0.009 & - & - & - & - \\
\hline \multicolumn{7}{|l|}{ LEPR genotype Gln223Arg } \\
\hline $\mathrm{Gln} / \mathrm{G} \ln$ & - & - & 1 & 1 & & \\
\hline Gln/Arg+Arg/Arg & - & - & $3.30(1.37-7.93)$ & 0.008 & $2.40(0.95-6.08)$ & 0.065 \\
\hline \multicolumn{7}{|l|}{ Tumor size $(\mathrm{T})^{\mathrm{c}}$} \\
\hline $\mathrm{T} 1+\mathrm{T} 2$ & 1 & 1 & 1 & & & \\
\hline T3 & $1.13(0.36-3.56)$ & 0.833 & $1.04(0.34-3.15)$ & 0.946 & $1.22(0.37-4.02)$ & 0.740 \\
\hline $\mathrm{T} 4$ & $4.56(1.43-14.62)$ & 0.011 & $1.24(0.44-3.45)$ & 0.682 & $2.73(0.96-7.80)$ & 0.060 \\
\hline \multicolumn{7}{|l|}{ Differentiation } \\
\hline Well differentiated & 1 & - & - & - & - & \\
\hline Moderately differentiated & $2.33(0.79-6.91)$ & 0.126 & - & - & - & - \\
\hline Poorly differentiated & $3.61(0.31-42.76)$ & 0.309 & - & - & - & - \\
\hline \multicolumn{7}{|l|}{ Lymph node $(\mathrm{N})^{c}$} \\
\hline Absent $(\mathrm{N}-)$ & - & - & 1 & 1 & & \\
\hline Present $(\mathrm{N}+)$ & - & - & $4.67(1.61-13.59)$ & 0.005 & $6.67(2.24-19.87)$ & $<0.001$ \\
\hline \multicolumn{7}{|l|}{ Irradiated } \\
\hline No & - & - & 1 & 1 & & \\
\hline Yes & - & - & $0.23(0.08-0.68)$ & 0.008 & $0.56(0.18-1.70)$ & 0.304 \\
\hline
\end{tabular}

$\mathrm{OR}=$ odds ratio; $\mathrm{CI}=$ confidence interval. ${ }^{\mathrm{a}, \mathrm{b}}$ Values adjusted by multivariate-logistic regression; ${ }^{\mathrm{c}} \mathrm{TNM}$ classification 7th edn (UICC, 2009).

A

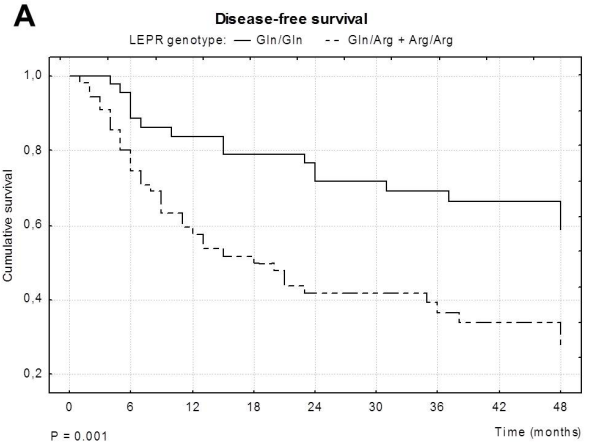

c

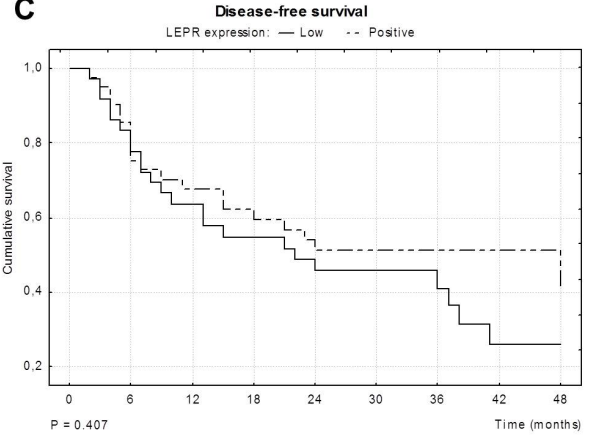

B Specific disease survival

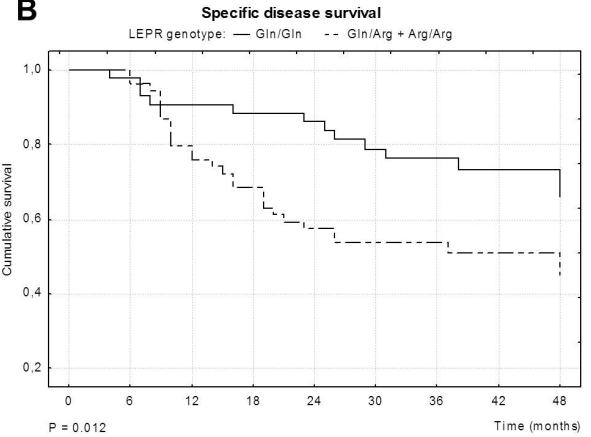

D

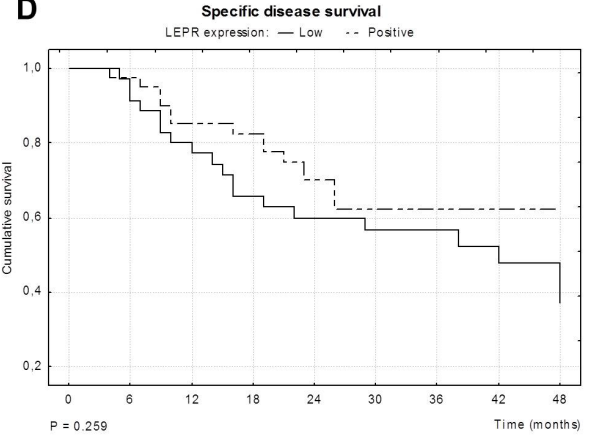

Figure 1. Survival plots. A. and B. Disease-free survival and disease-specific survival according to the LEPR Gln223Arg polymorphism. C. and D. Disease-free survival and disease-specific survival according to LEPR expression. 


\begin{tabular}{|c|c|c|c|c|}
\hline \multirow[t]{2}{*}{ Features } & \multicolumn{2}{|c|}{ Disease-free survival } & \multicolumn{2}{|c|}{ Disease-specific survival } \\
\hline & HR $(95 \% \mathrm{CI})^{\mathrm{a}}$ & $\mathrm{P}^{\mathrm{b}}$ & HR $(95 \% \mathrm{CI})^{\mathrm{a}}$ & $\mathrm{P}^{\mathrm{b}}$ \\
\hline \multicolumn{5}{|c|}{ LEPR genotype Gln223Arg } \\
\hline $\mathrm{Gln} / \mathrm{G} \ln$ & 1 & & 1 & \\
\hline $\mathrm{Gln} / \mathrm{Arg}+\mathrm{Arg} / \mathrm{Arg}$ & $2.38(1.29-4.39)$ & 0.006 & $2.11(1.05-4.24)$ & 0.036 \\
\hline \multicolumn{5}{|l|}{ Tumor size $(\mathrm{T})^{c}$} \\
\hline $\mathrm{T} 1+\mathrm{T} 2$ & 1 & & 1 & \\
\hline $\mathrm{T} 3$ & $1.22(0.58-2.54)$ & 0.598 & $1.27(0.52-3.11)$ & 0.604 \\
\hline $\mathrm{T} 4$ & $1.37(0.71-2.63)$ & 0.343 & $1.62(0.80-3.29)$ & 0.184 \\
\hline \multicolumn{5}{|l|}{ Lymph-node $(\mathrm{N})^{\mathrm{c}}$} \\
\hline Absent & 1 & & 1 & \\
\hline Present & $2.52(1.27-4.99)$ & 0.008 & $3.28(1.44-7.47)$ & 0.005 \\
\hline \multicolumn{5}{|l|}{ Irradiated } \\
\hline No & 1 & & 1 & \\
\hline Yes & $0.39(0.20-0.74)$ & 0.004 & $0.81(0.37-1.76)$ & 0.592 \\
\hline
\end{tabular}

\section{LEPR expression}

LEPR expression was evaluated in 87 tumors, which were classified as low $(40,46.0 \%)$ and high $(47,54.0 \%)$. LEPR expression did not show a significant association with tumor characteristics such as size $(\mathrm{P}=0.844)$, differentiation grade $(\mathrm{P}=0.761)$, lymphatic invasion $(\mathrm{P}=0.604)$, or perineural invasion $(\mathrm{P}=0.054)$, but was significantly associated with lymph node metastases $(\mathrm{P}=0.006$; Table 2). Multivariate analysis showed that low LEPR expression was an independent marker for lymph node metastases $(\mathrm{OR}=3.75,95 \% \mathrm{CI}=1.40-10.04$; Table 3$)$.

In contrast, LEPR expression did not significantly correlate with disease relapse $(\mathrm{P}=$ $0.149)$ or disease-specific death $(\mathrm{P}=0.123$; Table 2$)$, nor with disease-free or disease-specific survival $(\mathrm{P}=0.407$ and $\mathrm{P}=0.259$, respectively; Figure $1 \mathrm{C}$ and $\mathrm{D})$.

\section{DISCUSSION}

Leptin is a cell growth factor hormone that has been associated with tumor cell migration and invasion, as well as with angiogenesis in some tumors (Cleveland et al., 2010). LEPR is involved with several signaling pathways such as JAK/STAT, phosphatidylinositol 3-kinase, protein kinase $\mathrm{B}$, and mitogen activated protein kinase. These pathways, under leptin-LEPR control, are strongly related to cell survival and differentiation (Bracho-Riquelme et al., 2011).

The amino acid exchange caused by the LEPR Gln223Arg gene polymorphism yields a weaker interaction between leptin and its receptor, and as a consequence, reduction in cell growth signaling (Shuai and Liu, 2003). Our results show that the Arg223 homozygous genotype was associated with a 2.5 -times smaller risk of developing cancer than the Gln223 homozygous variant. Similar results have been reported in prostate cancer, suggesting that this allele increases tumor development risk (Monteiro et al., 2009). Therefore, Gln223Arg might play an important role in the inhibition of cell division (Yapijakis et al., 2009). In contrast, in breast cancer, it appears that the Arg223 allele increases cancer risk (Snoussi et al., 2006), shedding uncertainty regarding through which mechanism this allele impacts oncogenesis.

In comparison, our results suggest that the presence of $\operatorname{Arg} 223$ is associated with re- 
lapse risk and with worse disease-free and disease-specific survival. Similar studies in breast (Snoussi et al., 2006) and prostate cancer (Monteiro et al., 2009) have shown that patients carrying Arg223 have a significantly increased risk of relapse, and consequently worse prognosis. Reports that high levels of circulating leptin are related to decreased global survival of patients with breast cancer (Goodwin et al., 2005) and that weak interaction between leptin and LEPR favors angiogenesis and tumor growth (Kurahara et al., 1999; Ishikawa et al., 2006) support the hypothesis that the presence of Arg223 might result in worse prognosis in these patients. In contrast with these results, studies in lung (Li et al., 2012) and colorectal cancer (Liu et al., 2013) present the Gln223 allele as that related with worse prognosis.

According to our results, low LEPR expression increased the risk of lymph node metastasis by 4-fold when compared with that seen for tumors exhibiting strong expression. Weak LEPR expression had a similar effect as the Gln223Arg polymorphism, weak leptinLEPR interaction, and increased circulating leptin (Kurahara et al., 1999; Gröschl et al., 2005); these effects have been previously suggested as facilitators of tumor invasion and metastasis (Hohberger et al., 2008; Liu et al., 2013).

In conclusion, the present study attributed a protective role to the homozygous $L E P R$ Arg223 allele in oral and oropharyngeal cancer. Arg223 was shown to be an independent marker of worse prognosis, as illustrated by a lower disease-free and disease-specific survival. Low LEPR expression was found to be an independent marker of metastasis risk, showing a 4-fold increased risk of lymph node metastasis. These results suggest a tumor marker role for LEPR, as well as the potential for it to serve as a target for molecular therapies in patients with oral and oropharyngeal cancer.

\section{Conflicts of interest}

The authors declare no conflict of interest.

\section{ACKNOWLEDGMENTS}

We thank the GENCAPO (Head and Neck Genome Project: http://www.gencapo. famerp.br/) team for the invaluable discussions that motivated the present study. The authors acknowledge the financial support and researcher fellowships from Fundação de Amparo à Pesquisa do Estado de São Paulo (FAPESP), Conselho Nacional de Pesquisas (CNPq), and Fundação de Amparo à Pesquisa do Estado do Espírito Santo (FAPES).

\section{REFERENCES}

Andò S and Catalano S (2011). The multifactorial role of leptin in driving the breast cancer microenvironment. Nat. Rev. Endocrinol. 8: 263-275.

Anuradha C, Madan Ranjit P, Surekha D, Raghunadharao D, et al. (2012). Association of leptin receptor (LEPR) Q223R polymorphism with breast cancer. Global J. Med. Res. 12: 20-30.

Bauman JE, Michel LS and Chung CH (2012). New promising molecular targets in head and neck squamous cell carcinoma. Curr. Opin. Oncol. 24: 235-242.

Bracho-Riquelme RL, Loera-Castañeda V, Torres-Valenzuela A, Loera-Castañeda GA, et al. (2011). Leptin and leptin receptor polymorphisms are associated with poor outcome (death) in patients with non-appendicular secondary peritonitis. Crit. Care 15: R227.

Campos AH, Aldred VL, Ribeiro KC, Vassallo J, et al. (2009). Role of immunoexpression of nitric oxide synthases 
by Hodgkin and Reed-Sternberg cells on apoptosis deregulation and on clinical outcome of classical Hodgkin lymphoma. Mol. Cell Biochem. 321: 95-102.

Cleveland RJ, Gammon MD, Long CM, Gaudet MM, et al. (2010). Common genetic variations in the $L E P$ and $L E P R$ genes, obesity and breast cancer incidence and survival. Breast Cancer Res. Treat. 120: 745-752.

Ferlay J, Shin HR, Bray F, Forman D, et al. (2008). GLOBOCAN 2008, cancer incidence and mortality worldwide: IARC CancerBase No. 10. International Agency for Research on Cancer. Available at [http://globocan.iarc.fr]. Accessed October 20, 2014.

Frühbeck G (2006). Intracellular signalling pathways activated by leptin. Biochem. J. 393: 7-20.

Gallì P, Cadoni G, Volante M, De Feo E, et al. (2009). A case-control study on the combined effects of p53 and p73polymorphisms on head and neck cancer risk in an Italian population. BMC Cancer 9: 137.

Goodwin PJ, Ennis M, Fantus IG, Pritchard KI, et al. (2005). Is leptin a mediator of adverse prognostic effects of obesity in breast cancer? J. Clin. Oncol. 23: 6037-6042.

Gröschl M, Topf HG, Kratzsch J, Dötsch J, et al. (2005). Salivary leptin induces increased expression of growth factors in oral keratinocytes. J. Mol. Endocrinol. 34: 353-366.

He J and Chen WQ (2012). Chinese Cancer Registry Annual Report. Military Medical Science Press, Beijing, 12: 56-58.

Hedvat CV, Hegde A, Chaganti RS, Chen B, et al. (2002). Application of tissue microarray technology to the study of non-Hodgkin's and Hodgkin's lymphoma. Hum. Pathol. 33: 968-974.

Hohberger L, Wuerts BR, Xie H and Griffin T (2008). TNF- $\alpha$ drives matrix metalloproteinase-9 in squamous oral carcinogenesis. Laryngoscope 118: 1395-1399.

Hoon Kim J, Lee SY, Myung SC, Kim YS, et al. (2008). Clinical significance of the leptin and leptin receptor expressions in prostate tissues. Asian J. Androl. 10: 923-928.

Hsu FD, Nielsen TO, Alkushi A, Dupuis B, et al. (2002). Tissue microarrays are an effective quality assurance tool for diagnostic immunohistochemistry. Mod. Pathol. 15: 1374-1380.

Ishikawa M, Kitayama J and Nagawa H (2006). Expression pattern of leptin and leptin receptor (OB-R) in human gastric cancer. World J. Gastroenterol. 12: 5517-5522.

Kim EY, Chin HM, Park SM, Jeon HM, et al. (2012). Susceptibility of gastric cancer according to leptin and leptin receptor gene polymorphisms in Korea. J. Korean Surg. Soc. 83: 7-13.

Kurahara S, Shinohara M, Ikebe T, Nakamura S, et al. (1999). Expression of MMPS, MT-MMP, and TIMPs in squamous cells carcinoma of the oral cavity: correlations with tumor invasion and metastasis. Head Neck 21: 627-628.

Lavens D, Piessevaux J and Tavernier J (2006). Review: negative regulation of leptin receptor signaling. Eur. Cytokine Netw. 17: 211-219.

Leemans CR, Braakhuis BJM and Brakenhoff RH (2011). The molecular biology of head and neck cancer. Nat. Rev. Cancer 11: 9-22.

Li Y, Geng J, Wang Y, Lu Q, et al. (2012). The role of leptin receptor gene polymorphisms in determining the susceptibility and prognosis of NSCLC in Chinese patients. J. Cancer Res. Clin. Oncol. 138: 311-316.

Liu L, Zhong R, Wei S, Xiang H, et al. (2013). The leptin gene family and colorectal cancer: interaction with smoking behavior and family history of cancer. PLoS One 8: e60777.

Miller SA, Dykes DD and Polesky HF (1988). A simple salting out procedure for extracting DNA from human nucleated cells. Nucleic Acids Res. 16: 1215.

Monteiro C, Ribeiro R, Azevedo A, Cunha V, et al. (2009). Leptin receptor genetic variants are associated with prostate cancer development, aggressiveness and the time to biochemical relapse. EJC Suppl. 7: 412-413.

Park J and Scherer PE (2011). Leptin and cancer: from cancer stem cells to metastasis. Endocr. Relat. Cancer 18: C25-C29.

Rimm DL, Camp RL, Charette LA, Olsen DA, et al. (2001). Amplification of tissue by construction of tissue microarrays. Exp. Mol. Pathol. 70: 255-264.

Shuai K and Liu B (2003). Regulation of JAK-STAT signaling in the immune system. Nat. Rev. Immunol. 3: 900-911.

Snoussi K, Strosberg AD, Bouaouina N, Ben Ahmed S, et al. (2006). Leptin and leptin receptor polymorphisms are associated with increased risk and poor prognosis of breast carcinoma. BMC Cancer $6: 38$.

Soini Y, Kahlos K, Puhakka A, Lakari E, et al. (2000). Expression of inducible nitric oxide synthase in healthy pleura and in malignant mesothelioma. Br. J. Cancer 3: 880-886.

UICC (2009). TNM: Classification of Malignant Tumours. 7th edn. (Sobin LH, Gospodarowicz MK and Wittekind C, eds.). Wiley-Blackwell, Hoboken.

Vaisse C, Halaas JL, Horvath CM, Darnell JE, et al. (1996). Leptin activation of Stat3 in the hypothalamus of wild-type and ob/ob mice but not db/db mice. Nat. Genet. 14: 95-97.

Wazir U, Al Sarakbi W, Jiang WG and Mokbel K (2012). Evidence of an autocrine role for leptin and leptin receptor in human breast cancer. Cancer Genomics Proteomics 9: 383-387.

Yapijakis C, Kechagiadakis M, Nkenke E, Serefoglou Z, et al. (2009). Association of leptin -2548G/A and leptin receptor Q223R polymorphisms with increased risk for oral cancer. J. Cancer Res. Clin. Oncol. 135: 603-612. 